\title{
Online Shopping and Customers' Satisfaction in Lagos State, Nigeria
}

\author{
Omoneye 0. Olasanmi \\ Department of Management \& Accounting, Obafemi Awolowo University, Ile-Ife, Nigeria \\ Email: neyeolasanmi@yahoo.com
}

How to cite this paper: Olasanmi, O.O. (2019) Online Shopping and Customers' Satisfaction in Lagos State, Nigeria. American Journal of Industrial and Business Management, 9, 1446-1463.

https://doi.org/10.4236/ajibm.2019.96095

Received: April 27, 2019

Accepted: June 27, 2019

Published: June 30, 2019

Copyright $\odot 2019$ by author(s) and Scientific Research Publishing Inc. This work is licensed under the Creative Commons Attribution International License (CC BY 4.0).

http://creativecommons.org/licenses/by/4.0/ (c) (i) Open Access

\begin{abstract}
This study ascertained the level of awareness of customers to online shopping, and examined the relationship between online shopping and customers' satisfaction. It also investigated how certain factors influenced customers' satisfaction by prompting the usage of online shopping. Primary data was used for the study and a structured questionnaire was administered to obtain the data. The population for the study consisted of individuals from different occupations within Lagos, Nigeria, who had ever purchased items online, while purposive and convenience sampling techniques were used in selecting the respondents. Data collected were analysed using frequency counts and regression analysis. Results revealed that over $50 \%$ of the respondents engaged in online shopping regularly. It was also discovered that different reasons were suggested for preferred specific online retailers such as convenience, availability of better product information, availability of a variety of product to choose from and better prices than others. It was further revealed that usage of online shopping represented by costs involved, level of awareness, time and convenience, quality of products and risks involved, had significant relationships on customer satisfaction. The study concluded that improved customer satisfaction can in turn impact on continued patronage of online shopping outlets.
\end{abstract}

\section{Keywords}

Online Shopping, Online Retailing, Customer Satisfaction

\section{Introduction}

The usefulness of the Internet cannot be overemphasized; its inception has had tremendous effects on how individuals and organisations communicate and interact all around the world [1]. It is an undeniable fact that it has provided new 
opportunities for the marketing and business sector of the global economy. With the Internet, one spends less to reach out to even more people than one normally would with conventional advertising means such as billboards, radio jingles, television adverts, etc. Many people now have access to the Internet due to it being relatively cheap and easily accessible from almost anywhere in the world. The Internet is essentially now a vital part of our everyday lives.

Technology keeps advancing every day and spreading fast across the world. This has provided several businesses an opportunity to take advantage of by having an edge to reach a high number of people through the simple medium of the Internet. Businesses can advertise and even sell their goods online. This process of selling goods online is what is referred to as online retailing. It is otherwise referred to as online shopping, e-commerce, e-shopping, Internet shopping and so on [2]. These various terms may be used interchangeably during the course of this study.

The online business sector is regarded as the most advanced in the application of new and innovatory Internet technologies when providing market services through the Internet [3]. Online retailing has provided a means of improving the conventional forms of business. The Internet provides a very productive retail medium that major retailers are keen to exploit for strategic gain [4]. There have been some massive changes in how customers have altered their methods of shopping and accepted online shopping.

In Nigeria, in spite of the serious economic problems the country is facing such as low income per capita and irregular power supply, Internet usage is increasing at a very high rate. This new trend of online shopping is now being embraced by businesses with physical stores such as SLOT (which is an enterprise that is into the sale of electronic gadgets such phones, tablets, phone pouches, etc., on a very large scale). They now operate online stores in addition to physical outlets. Large Internet retailers such as KONGA and JUMIA also operate a system for third-party merchants to use their platform to advertise and sell their goods. Other sites such as OLX.com, KAYMU.com, and JIJI.ng are essentially online marketplaces, which are made up of various individual sellers who advertise their products free and directly interact with customers. They are essentially sites where buyers and sellers meet.

Various participants in online shopping have various reasons for participating and therefore, their expectations would differ from each other and would be measured differently. For example, the owners of the business main concern or expectations would be based on the amount of profit made. Customers, however, would be interested in different things from the owners. Their perspective on performances of online retailers would be on the basis of the level of satisfaction they feel they derived from the provision or use of products or services by the business. Online retailing business is fast becoming highly competitive and just as in any other type of competitive market; the main objective should be attracting the largest customer base, which cannot be achieved if the customers are not satisfied with the business. The focus should, therefore, be to satisfy the custom- 
ers and provide them with enough reasons to justify why they should not switch to competitors. Furthermore, within the context of this study, usage of online shopping was examined based on the following identifiable variables: quality of the product or service, time and convenience, risks involved and costs involved. If customers are satisfied with the level of services provided to them, there is a high probability that they will continue to patronize such retailers. Previous studies include [5] and [6]. However, none of them focused on customers' satisfaction; they focused more on identifying factors that play on customers' minds when shopping online. This study thus set out to find out what factors, within Nigeria, could make customers satisfied with online shopping, such that they would continually be forced to patronize such online retailers.

\section{Statement of the Problem}

A large number of firms are creating and exploiting various business opportunities over the Internet and many more firms are expected to follow suit [7]. Just as in any business, the customers are the backbone on which the business is based; without customers, the business has no basis on which to operate.

This research emerged from the fact that there is a need for adequate knowledge of customers' actual perception of Internet shopping in Nigeria and how that in turn affects their levels of satisfaction. In a country such as Nigeria where there is an evidently high rate of fraudulent activities over the Internet, many people would be skeptical about conducting business over the Internet. This, however, could be a matter of perception that Internet retail business may just be providing an avenue for fraudsters to perpetuate crime.

Global technology keeps advancing at a fast rate around the world and a large number of people appear to be embracing such advancements. Online shopping or online retailing is one of such technological advancements. Some people come into online shopping transactions with rather skeptical minds and believe no good can come out of it. However, such mindsets could invariably play upon the satisfaction they might derive from such transactions. It is of paramount importance to understand what the factors are that could sway customers in their decision making as regards patronage of Internet retailers and upon identifying such factors, there is the need for the Internet retailers to find ways to address such factors to ensure customers are satisfied enough to continue patronizing them. A whole lot of factors could affect how customers rate performances of online retailers. Such factors include; issues of fraud, authenticity of transaction, trust, ease of navigation through websites, options for the return of goods if customers are not satisfied, time saved, costs, conformity of goods delivered to those illustrated online, quality of the goods, etc. These are factors that could affect perceived performance rating of online retailers by the customers, which could in turn affect customers' satisfaction and determine whether they keep patronizing such online retailers or online retailing as a whole.

Online shopping attracts different types of customers and they do not all possess or hold the same perception of it. There are different forces that could in- 
fluence consumers' attitudes towards online shopping and this in turn influences satisfaction [8]. These days, the Internet serves not only as a platform for networking, but also as a medium through which businesses can bond with their customers [9].

Consequently, it is essential to identify and analyze the factors, which could influence customers to shop online and how those factors could influence customer satisfaction. This study, therefore, aimed to examine the extent to which customers are aware of online shopping and its benefits as well as how its usage influences customer satisfaction. It also aimed at providing evidence on customers' perception of current practices in online shopping, which could assist the online retailers in enhancing their performances.

\section{Objectives of the Study}

The specific objectives of this study were to:

1) ascertain customers' level of awareness of online shopping and its benefits;

2) examine the factors prompting the use of online shopping by customers;

3) determine if customers are satisfied with online shopping; and

4) determine how the usage of online shopping influences customer satisfaction.

\section{Hypothesis of the Study}

$\mathrm{H}_{0}$ : There is no significant relationship between online shopping usage and customer satisfaction.

\section{Literature Review}

\subsection{Online Shopping/Internet Retailing}

The existence of the Internet as a business tool has provided firms with an opportunity to stay competitive by providing their customers with a highly fast, relatively cheap and easy way of making purchases. Online shopping otherwise referred to as online retailing simply means retailing activities conducted online through the Internet [4]. It is a process of exchanging of goods and services through the World Wide Web [10]. Since it started out in the mid-1990s, online retailing business has grown rapidly and is growing at a faster rate than retailing in general [11]. The Internet provides a way for organisations to increase their profit margins as new and existing companies/organisations are creating websites, while many are now operating online stores in addition to their physical stores. Having a website is highly significant to businesses as it provides an avenue for marketing and advertising as well as developing and managing customer relations. There are various factors that could appeal to customers to shop online; examples of such factors include the ease, speed and lower level of stress involved as compared to physical shopping, and also customers can purchase items at any time of the day that proves convenient to them [5].

It has been argued by [12] that, "the capacity of the Internet to provide infor- 
mation, ensure communication with customers, allow for collection of market research statistics, promote goods and services and support online booking and purchase of goods and services, as well as adding a new channel for retailers to conduct their business". According to these authors, some major features of online retailing websites include: virtual interactions between buyer and seller; a set of complex network links; the use of large, functional product images to describe products; presence of product reviews by specialists as well as previous customers; layered and faceted navigation that allows shoppers find what they need with ease and the ability to allow searching for certain items on the website.

Due to technological advancements, conventional methods of shopping have become rather insufficient for Individuals and many now seek less stressful ways to shop their favorite stores. The Internet has modified the fundamentals of customers as regards their notions relating to convenience, speed, price, product information and service. As a result, it has provided marketers with a new way through which they can create value for their customers and create strong relationships with them [13].

It is a widely acclaimed fact that the ability of the Internet to allow for interaction provides retailers with the key to transforming the shopping experience of customers [14] [15] and create stronger positions for themselves competitively [16] [17]. The Internet provides retailers with a channel through which they can enlarge their target markets, improve upon relationships with customers, add more product lines, ensure better cost efficiency and deliver customized offers [18].

A study by two authors [19] is of the view that online shopping is the third highest activity conducted over the Internet. They reiterated that online shopping beats other activities such as e-mail usage, instant messaging and web browsing.

\subsection{Online Shopping/Retailing in Nigeria}

Internet shopping is fast becoming increasingly popular in Nigeria due to the convenience it offers and the reasonable prices of goods and services available online. Visiting stores can be quite stressful especially in cities such as Lagos, Port-Harcourt, Abuja, Calabar, Ibadan, Kaduna and Kano with the high rate of traffic. The introduction of online retail stores such as Konga.com, Jumia.com, and various other stores, online shopping platforms seem to have become a viable option for modernday Nigerians just like Amazon, eBay and Aliexpress.

Nigeria is the fastest growing telecommunications country in Africa [20] the country has witnessed an upsurge in the number of Internet retailers (e-tailers) who attract shoppers into their web sites and encourage them to window shop, search for products, make price comparisons, and ultimately purchase products. Some of the more prominent e-tailers in Nigeria include Jumia.com.ng, Konga.com, Kaymu.com, Dealdey.com, Slot.ng, Taafoo.com and a host of others. According to Philips consulting online shopping report [6], Nigeria records over 1-billion-naira worth of transactions monthly with over 500 orders per day. The 
top 20 online stores in Nigeria based on the criteria of social media community activities, number of visitors to websites, customers review, website design, and delivery speed, among others are listed as [21]: Buyam.com.ng, Adibba.com, Ojashop.com, Mystore.com, Regalbuyer.com, Fouani.com (LG products), Gloo.ng, Gidimall.com, Kara.com.ng, Supermart.ng, Yudala.com.ng, Jiji.ng, Parketonline.com, Kaymu.com.ng, Dealdey.com, Taafoo.com now Coliseum, OLX.com.ng, Slot.ng, Konga.com, Jumia.com.ng. In this present-day, the level of customer's loyalty depends upon the consistency of the retailer in delivering quality, value and satisfaction [22]. When customers need certain products or services, they could search for them by browsing the Internet [23] [24]. Many times, would-be customers are enticed by the information they receive on the Internet, about the products they may need. They notice many products online, choose and purchase the one they best prefer.

\subsection{Customer Satisfaction}

"Customer satisfaction is the evaluation of an experience rendered" [25]. It is also the process through which consumers respond upon evaluation of perceived discrepancies between expectations and actual performance of the product after using it [26].

It is assumed that, when a customer is pleased with the provision of a product or service, it is termed satisfaction. Satisfaction also refers to a person's feelings of pleasure or displeasure from comparing expectations with a product's performance [27]. Satisfaction is a state of being happy with the outcome of a situation. However, satisfaction is relative and this implies that it is sometimes not possible to satisfy everybody. Levy [28] advocated how to measure customer satisfaction in the forms of surveys where feedback from customers can be quantitatively measured, focus groups can be organized where discussions led by a trained moderator reveal show customers feel.

\subsection{Theoretical Framework}

This study adopted the Technology Acceptance Model (TAM). The Technology Acceptance Model (TAM) was developed to study the adoption and levels of diffusion of new technology at individual levels, and to clarify computer usage behavior. TAM essentially refers to how a user accepts new technology. TAM outlines factors that could influence how a user accepts and uses specific technology [29] [30]. The basic factors in TAM are Perceived Usefulness (PU) and Perceived Ease of Use (PEOU). Davis defines Perceived Usefulness as the "the degree to which a person believes that using a particular system would enhance his or her job performance" and Perceived Ease of Use (PEOU) is the "degree to which a person believes that using a particular system would be free from effort" [31]. It is assumed that perceived usefulness and perceived ease of use of online shopping will affect the attitudes of the individual towards adopting online shopping technology. This in turn leads to a behavioural intention to use such technology and then this leads directly to actual use of the online shopping sys- 
tem to make an actual purchase or some other form of transaction. In other words, the user would first consider the ways in which he/she would be free from effort in terms of the ease of using online shopping sites. This leads to him/her thinking that using such online shopping sites could increase his performance and then he/she moves forward to develop the intention to use before finally using the system.

\subsection{Empirical Review of Literature}

Jarvanpaa and Todd [31] in one of the earliest studies on online shopping, carried out a study on attitudes and intentions towards Internet shopping in general. The study realized several perceptual indicators that belonged to four major categories: the value of the product sought by the consumer, the shopping experience, the quality of service offered by the Web site, and risk perceptions of Internet retail shopping. Vellido, Lisboa and Meehan [32] in a study on quantitative characterization and prediction of online purchasing behavior aimed to discover factors, which could influence user's perceptions towards online shopping. Risk perception was discovered to be the main factor, which influences whether or not people buy online. Other factors include; control and convenience of the shopping process, affordability of merchandise, customer service and ease of use of the shopping site. Chung-Hoon and Young-Gul [33] carried out a study, which sought to identify key factors that influence consumer purchase behavior in an online shopping setting; they investigated the relationship which exists between the various characteristics of online shopping and consumer purchase behavior. The results indicated that information quality, user interface quality, and security perceptions affect satisfaction and benefits. Flick [34] carried out a study, which sought to assess acceptance of online shopping by examining factors affecting customers' intentions to purchase. The study concluded that ease of use is positively associated with trust which is in turn positively associated with online purchase intentions, it also identifies web site attractiveness as a critical factor in the development of trust and invariably online purchase intentions. Cheung, Chan and Limayem [35] in a review of online consumer behavior concluded that consumers' perception of risks involved in online shopping has a massive effect on their decision to engage in it and in addition, satisfaction with their online shopping experience determines whether or not they would retain online shoppers. Chaffey \& Ellis-Chadwick [36] are of the opinion that many online purchasers have been ascertained to never visit a certain website again if they had previous bad experiences. Shopping enjoyment on the Internet is significantly related to attitudes and intention to shop on the Internet. To meet up with customers' desire for control and convenience, online stores would have to design efficient systems to enable customers to find what they need with ease [37].

Syed \& Norjaya [38] investigated the antecedents of customer satisfaction in online shopping. They aimed to identify the factors that are key to influencing 
customer satisfaction. They concluded that website design, reliability, product variety and delivery performance were the key factors that influence consumers' satisfaction with online shopping. Binod \& Neeraj [5], in another study aimed to determine factors which are important to customers in shopping online and found the following to be of most importance to customers when shopping online; time saved, difficulty in shopping, risks involved, lower prices, quality of product, product delivery and information available. Shariful [39] aimed to analyze what are those factors affecting online shopping behavior of consumers. The study identified that financial risks and non-delivery risk negatively affected customers' attitudes toward online shopping and concluded that attitudes toward online shopping positively affected online shopping behavior of consumers. In a publication of Kaymu Global [40], it was discovered that people are likely to come back to shop on e-commerce sites if they are happy with previous purchase experiences, accessibility of the website, pricing of products or services (whether it is better or cheaper elsewhere). The study concluded that these factors would influence their future decisions regarding making online purchases. In a study on the impact of non-store retailing on consumers' satisfaction in Calabar, Nigeria [41], it was revealed that consumers' in Calabar Metropolis perceived Internet shopping to be risky, and consumers' perception of Internet shopping suitability positively affects or predicts consumers' satisfaction and finally, that consumers' perception of risk in Internet shopping is negatively associated with consumers' satisfaction. Akbar \& James [42] indicated that there are nine critical factors, which could influence Internet users to accept online shopping and these are: price, refund, convenience, auction websites, promotion, brand, search engines, security and online shopping malls. The relationship between the nine critical factors was measured against receptivity to online shopping and the results suggested that all nine variables had a positive statistically significant effect to Internet users to accept online shopping. They suggested that online business owners should implement these nine factors.

Ayo, Adewoye and Oni [43] investigated issues in consumers' adoption of B2C (Business to Customer) e-commerce in Nigeria. The study involved population who are computer literate and familiar with the use of the Internet. An extended Technology Acceptance Model (TAM) with task-technology fit, perceived risk and trust was developed and tested using linear regression. The results revealed that significant relationships existed between the variables. Olusoji, Ogunkoya, Lasisi \& Elumah [44] in a study on risk and trust in online shopping, argue that since online vendors are the customer's focal point, trust is built on their perceptions of the vendors. Perceived usefulness and perceived ease of use of online shopping were also examined to find out whether the Nigeria populace sees a need for online shopping or even e-commerce. Some of the perceived risks identified are financial, product performance, social, psychological and time/convenience. Findings reveal that the presence of perceived risk negatively affects trust in online shopping. 


\section{Methodology}

The study area for this study was limited to Lagos metropolis. The choice of Lagos as the area of study was a rather straightforward one as Lagos state represents the most populated state of the southwest and is essentially the most economic as well as the busiest state in not only the southwestern part of Nigeria but the entire country as a whole [45]. Purposive and convenience sampling techniques were employed in this study because the selection of individuals that constituted the respondents of the study was based on those who were considered able to adequately assist the research by providing the necessary information needed for the execution of this research.

The sample size required this study was calculated based on the formula by Rose, Spinks and Isabel-Canhoto [46] required to estimate a proportion of an infinite population with an approximate $95 \%$ confidence level. This formula is given by:

$$
n_{r}=\frac{4 p q}{d^{2}}
$$

where $n_{r}=$ required sample size,

$p=$ proportion of the population having the characteristic,

$q=1-\mathrm{p}$,

$d=$ the degree of precision.

The proportion of the population $(p)$, which is unknown, is 0.5 , which assumes maximum heterogeneity (i.e. a 50/50 split). The degree of precision (d) is the margin of error that is acceptable.

Out of the 400-sample size estimated for this study, 354 questionnaires were adequately completely by the respondents, and were used in the analysis of the study.

Data was gathered from primary sources with the use of a structured questionnaire. A 31-item questionnaire was designed to collect data on demography, customers' level of awareness of Internet retail, customer experience regarding customer service and customers' thoughts and opinions on current practices in online retail. The questionnaire was distributed to individuals who have one time or the other engaged in online shopping. Reliability was tested by the use of 40 questionnaires, which were randomly selected individuals. The 40 questionnaires were coded and imputed into SPSS and the results showed a Cronbach alpha correlation coefficient of 0.794 which was concluded to be high enough for the study.

Online shopping usage is the independent variable and was represented by some factors: level of awareness, quality of products or services, costs, risks and time/conveniences.

Customer satisfaction is the dependent variable and in the context of this study was expressed in the questionnaire on a 5-point Likert scale ranging from very satisfied to very dissatisfied.

This study examined factors involved in online shopping influence, which 
were: Level of Awareness, Time and Convenience, Quality of Products or Services, Costs involved, and Risks involved. The model specification was thus built around these variables, that is,

Customer Satisfaction $(C S)=f$ (online shopping)

$C S=f($ Level of Awareness, Time \& Convenience, Quality of Products or Services, Costs involved, Risks involved)

$$
C S=\alpha_{0}+\alpha_{1} L A+\alpha_{2} T C+\alpha_{3} Q P+\alpha_{4} C I+\alpha_{5} R I+\varepsilon_{0}
$$

where;

$$
\begin{aligned}
& C S=\text { Customer Satisfaction, } \\
& L A=\text { Level of awareness, } \\
& T C=\text { Time \& Convenience, } \\
& Q P=\text { Quality of products or services, } \\
& C I=\text { Costs involved, } \\
& R I=\text { Risks involved, } \\
& \varepsilon_{0}=\text { Error term. }
\end{aligned}
$$

\section{Discussion of Findings}

Data collected were analyzed using Statistical Package for the Social Sciences (SPSS) software. Four hundred copies of the questionnaire were administered to respondents of various ages, tribes, religion, educational background and gender, however only 358 copies were adequately completed which represent a reasonable return compared to the sample size.

The gender distribution of the respondents was almost of equal representation with 189 (52.8\%) being male and $169(47.2 \%)$ of the respondents being female. As regards the age distribution, $43.3 \%$ of the respondents were between the ages of $18 \%$ to $30 \%, 41.3 \%$ of the respondents were between ages 31 to 40 , while those above 40 years but less than 50 stood at $11.7 \%$ and about $3.7 \%$ were above 50 years of age. This distribution shows that a vast majority of the respondents were between the ages of 18 and 40, which indicates that most participants in online transaction were young people. In terms of educational background of respondents, results show that $20.4 \%$ hold at least SSCE qualification, $20.1 \%$ claimed to have obtained NCE/OND as their highest qualification, 36.6\% of the respondents claimed to possess HND/B.A/B.Sc./B.Ed. certificates while $20.9 \%$ possess higher degrees such as masters' degrees and PhDs. This implies that information obtained from respondents is reliable.

\subsection{Customers' Level of Awareness of Online Shopping and Its Benefits}

In ascertaining customers' level of awareness of online shopping and its benefits, descriptive statistical tools were adopted by reporting the frequency distribution and median of items related to the awareness of online shopping by the respondents. From Table 1, the majority of the respondents asserted that they shopped online at least once every two- three months. This proportion represents about 
Table 1. Awareness of online shopping and its benefits.

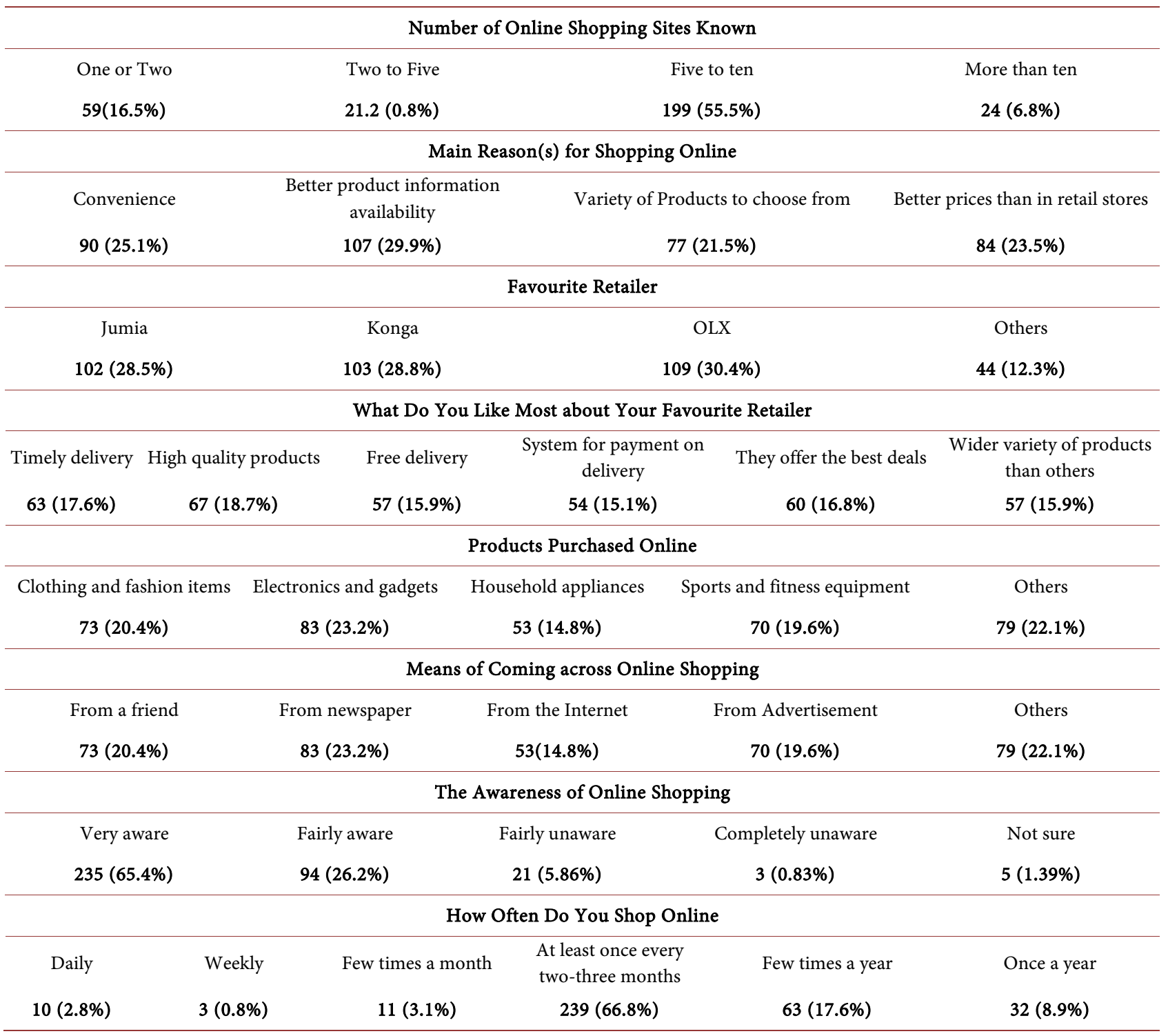

Source: Field Survey (2018).

$66.8 \%$ of the respondents. Just $2.8 \%$ shop online daily, $0.8 \%$ shop online weekly, about $17.6 \%$ shop online monthly. $8.9 \%$ of the respondents' shop online at least once a year. In identifying their reasons for shopping online, $25.1 \%$ claimed that convenience is the main reason why they shop online. $29.9 \%$ asserted that availability of better product information led to their decision to shop online, $21.5 \%$ were of the opinion that availability of a wide variety of products to choose from encourages them to shop online, while $23.5 \%$ were of the view that online shopping provided them with better prices than others. The respondents submitted that OLX is their most preferred online retailer (30.4\%), followed by Konga (28.8\%) and Jumia (28.5\%). High-quality products (18.7\%) were described by the respondents as the key factor that made them select their favourite retailer, $17.6 \%$ of the respondents claimed that timely delivery was the major reason why they preferred their favourite retailer, while $15.9 \%$ cited free delivery, and $15.1 \%$ 
asserted that system for payment on delivery was their main reason. Some even cited availability of a wider variety of products (15.9\%). Electronics and gadgets ranked as the most purchased goods online (23.2\%), followed by others such as software, music, videos and CDs and DVDs (22.1\%). 20.4\% purchase clothing and fashion items, while $19.6 \%$ purchase sports and fitness equipment. $16.5 \%$ of the respondents claimed to be aware of one or two online shopping sites, $21.2 \%$ of respondents said they were aware of two to five sites, $55.5 \%$ claimed that they know more than five sites.

Results indicate that more than half of the respondents know more than five online shopping sites and came across them through different means such as newspapers, adverts, etc. Most of the respondents shop online at least once every two-three months. In addition, it was noted that customers are not limited to the scope of products they purchase online. Buying and selling have become an important part of many people's lives. Students and parents rely on the Internet to acquire and sell textbooks at affordable prices, virtual stores allow people to shop from the comfort of their homes without the pressure of a salesperson, and online marketplaces provide a new and more convenient venue for the exchange of virtually all types of goods and services. It was also discovered that customers have various reasons for shopping online. Fashion designers could purchase clothes and materials online, technicians could purchase tools for their works, etc. This is in agreement with Syed and Norjaya [38] who identified product variety and delivery performances as the key factors that influenced consumers' satisfaction of online shopping.

\subsection{Factors Prompting the Use of Online Shopping by Customers}

From Table 2, some factors which influence the use of online shopping have been brought to light. As regards the availability of products, over $80 \%$ of respondents agreed that this is an important factor influencing users' choice of online shopping. This shows that online stores do indeed offer a wide variety of products and is a sufficient factor to influence customers' patronage. In the same vein, it could be asserted that online shopping offers greater comfort and convenience, as evidenced by $81.2 \%$ of the respondents agreeing with this factor. Regarding time efficiency of online shopping, respondents generally accepted it with more than $75 \%$ agreeing that online shopping saves time. In addition, online shopping reduces travel necessity; over $75 \%$ agreed, while less than $25 \%$ disagreed, this supports the notion that customers can obtain and compare prices online with price information easily available on the Internet. This development established the reason why more than $75 \%$ of the respondents agreed with the fact that shopping online is less costly than conventional shopping. Most of the respondents claimed they were satisfied with their overall online shopping experiences. These thus shows that the factors listed: time savings, timely delivery, fast shipping, convenience \& comfort, price, availability of a wide range of products and reduced travel necessity do greatly influence customers in their use of online shopping. This is in agreement with works such as Vellido, Lisboa and 
Table 2. Factors influencing the use of online shopping by customers.

\begin{tabular}{cccccc}
\hline Factors & $\begin{array}{c}\text { Strongly } \\
\text { Agreed }\end{array}$ & Agreed & Undecided & Disagree & $\begin{array}{c}\text { Strongly } \\
\text { Disagree }\end{array}$ \\
\hline $\begin{array}{c}\text { Availability of wide } \\
\text { variety of products }\end{array}$ & $144(40.2 \%)$ & $147(41.1 \%)$ & $21(5.9 \%)$ & $28(7.8 \%)$ & $18(5.0 \%)$ \\
Comfort and convenience & $148(41.3 \%)$ & $143(39.9 \%)$ & $20(5.6 \%)$ & $24(6.7 \%)$ & $23(6.4 \%)$ \\
Saves time & $152(42.6 \%)$ & $140(39.1 \%)$ & $19(5.3 \%)$ & $18(5.0 \%)$ & $29(8.1 \%)$ \\
Reduces travel necessity & $157(43.9 \%)$ & $133(37.2 \%)$ & $21(5.9 \%)$ & $25(7.0 \%)$ & $22(6.1 \%)$ \\
Timelines of delivery & $146(40.8 \%)$ & $150(41.9 \%)$ & $19(5.3 \%)$ & $24(6.7 \%)$ & $19(5.3 \%)$ \\
Better price offers & $127(35.5 \%)$ & $167(46.6 \%)$ & $22(6.1 \%)$ & $24(6.7 \%)$ & $18(5.0 \%)$ \\
Fast shipping & $139(38.8 \%)$ & $146(40.8 \%)$ & $25(7.0 \%)$ & $22(6.1 \%)$ & $26(7.3 \%)$ \\
\hline
\end{tabular}

Source: field survey (2018).

Meehan [32] who listed convenience of the shopping process as one of the major factors influencing customers' perceptions towards online shopping. This means the easier it is for customers to engage in online shopping the more likely they are to engage in it. Binod and Neeraj [5] suggested that time saved, lower prices as well as product delivery are of most importance to customers in online shopping. If customers can get goods online at relatively cheap prices, they are more than likely to continue patronizing such outlets. This is also in line with the submissions of Esiri [40] who stated that customers are more likely to come back if they are happy with previous purchase experiences as regards pricing of products and services.

\subsection{Online Shopping and Customer Satisfaction}

In order to determine how the usage of online shopping influences customer satisfaction, both inferential and descriptive statistic measures were employed. In Table 3(a), satisfaction was categorized into five scales namely: very dissatisfied, dissatisfied, neutral, satisfied and very satisfied. $22.3 \%$ of the respondents were very satisfied with the quality of products purchased online, $22.1 \%$ were satisfied, $19.8 \%$ were neutral, $19.8 \%$ were dissatisfied and $15.9 \%$ very dissatisfied. Over $40 \%$ of the respondents were satisfied, while less than $40 \%$ were not satisfied. $20.4 \%$ were very satisfied with the prices of goods sold online, while $16.8 \%$ were very dissatisfied, $20.7 \%$ were just dissatisfied. The proportion of respondents who are neutral stood at $19.3 \%$, and those who were just satisfied represent about $22.9 \%$. It is also clear that more than $40 \%$ of the respondents were satisfied with the prices of goods sold online. $23.2 \%$ of the respondents were satisfied with the timeliness of delivery of online shopping, while $21.8 \%$ were very satisfied although, $16.2 \%$ were not satisfied and $21.5 \%$ were very dissatisfied. More respondents were satisfied with their overall online shopping experience (43.5\%) than those who were not satisfied (35\%). Overall, this shows that more people were satisfied with online shopping than those who were not; the gap was not as wide, and this means that those satisfied with online shopping and those not satisfied were of almost equal proportions. There are various reasons why this 
Table 3. (a) Online shopping and customer satisfaction; (b) Online shopping usage and customer satisfaction.

(a)

\begin{tabular}{cccccc}
\hline Constructs & $\begin{array}{c}\text { Very } \\
\text { Dissatisfied }\end{array}$ & Dissatisfied & Neutral & Satisfied & $\begin{array}{c}\text { Very } \\
\text { Satisfied }\end{array}$ \\
\hline $\begin{array}{c}\text { The quality of products } \\
\text { purchased online }\end{array}$ & $57(15.9 \%)$ & $71(19.8 \%)$ & $71(19.8 \%)$ & $79(22.1 \%)$ & $80(22.3 \%)$ \\
$\begin{array}{c}\text { The prices of goods sold online } \\
\text { The timeliness of delivery }\end{array}$ & $60(16.8 \%)$ & $74(20.7 \%)$ & $69(19.3 \%)$ & $82(22.9 \%)$ & $73(20.4 \%)$ \\
$\begin{array}{c}\text { The amount of risks involved in } \\
\text { online shopping }\end{array}$ & $67(18.7 \%)$ & $72(20.1 \%)$ & $67(18.7 \%)$ & $76(21.2 \%)$ & $76(21.2 \%)$ \\
Your overall online shopping & $58(16.2 \%)$ & $62(17.3 \%)$ & $83(23.2 \%)$ & $78(21.8 \%)$ \\
experience & $66(18.4 \%)$ & $63(17.6 \%)$ & $73(20.4 \%)$ & $76(21.2 \%)$ & $80(22.3 \%)$ \\
\hline
\end{tabular}

Source: Field survey (2018).

(b)

\begin{tabular}{lccccc}
\hline $\begin{array}{c}\text { Dependent } \\
\text { Variable }\end{array}$ & Parameter & $\boldsymbol{\beta}$ & $\mathbf{t}$ & Sig. & \\
\hline & Intercept & 1.738 & 10.887 & 0.000 & $\mathbf{F}=118.521(0.000)$ \\
Customer & Level of awareness & 0.041 & 6.724 & 0.000 & Adj. $^{2}=0.39$ \\
Satisfaction & Time \& Convenience & 0.033 & 2.173 & 0.040 & \\
& Quality of products or services & -0.012 & -0.299 & 0.765 & \\
& Risks involved & -0.056 & -3.011 & 0.001 & \\
\hline
\end{tabular}

Source: Author's computation (2018).

could be so such as risks in the forms of financial, psychological and Olusoji, Ogunkoya, Lasisi and Elumah [44] support this notion by opining that presence of perceived risk negatively affects trust in online shopping and this negatively affects trust in online shopping.

The study also adopted multivariate method of regression by taking into consideration the ordinal measures of the dependent variable. Table 3(b) reports the results of the regression. The result shows that explanatory variables explain about $54.7 \%$ of variation in customer satisfaction as it relates to online shopping. The F-statistics reports that the model is statistically significant and robust. The $\mathrm{R}^{2}$ reports that about $64.7 \%$ variation of the dependent variable was accounted for by the independent variable. The F-statistics shows that the model is statistically significant.

Cost involved has negative relationship with customer satisfaction $(\mathrm{t}=-4.573$, $\mathrm{p}<0.05)$. The coefficient of -0.066 shows that rises in cost will reduce customer satisfaction with online shopping. Level of awareness exhibits positive relationship with customer satisfaction $(t=6.724, \mathrm{p}<0.05)$ with coefficient of 0.04 . It shows that increase in level of awareness drives the customer satisfaction, in order words the more aware people are of online shopping and its features the higher their chances of being satisfied with its use. 
Time and convenience has positive relationship with customer satisfaction $(t=2.173, p<0.05)$. It implies that the less time and higher convenience of the customers' in shopping online, the more satisfied they would be. This is in agreement with Flick [34] who submitted that ease of use is positively associated with trust, which is in turn positively associated with online purchase intentions. Quality of products do not exhibit significant relationship with customer satisfaction $(t=-0.299, p>0.05)$. Risks involved has negative relationship with customer satisfaction $(\mathrm{t}=-3.011, \mathrm{p}<0.05)$. Many risks are involved with online shopping e.g. the product might not be delivered on time, a different product may be delivered instead, and the product could be damaged in the process of shipping. More so, the finding is in agreement with submission of Cheung, Chan \& Limayem [35] who concluded that consumers' perception of risks associated with online shopping has a pivotal effect on their decision to engage in it.

\subsection{Hypothesis Testing}

The results in Table 3(b) revealed that there is a significant relationship between online shopping usage through the interaction of its variables and customer satisfaction. Hence, the null hypothesis is rejected.

\section{Conclusion}

The study revealed that customers of online shopping are well aware of online shopping as a means of purchasing goods and also know the potential benefits using it brings to them. It was revealed as well that time and convenience is the most important factor influencing customers' decision to engage in online shopping while other factors such as risks involved are also equally as important. Other factors such as quality of products, costs and level of awareness are also important and play very significant roles in determining whether customers engage in online shopping. All these factors involved in the usage of online shopping have significant relationships with customer satisfaction, and customer satisfaction, in turn, can impact on continued patronage of online shopping outlets.

\section{Conflicts of Interest}

The authors declare no conflicts of interest regarding the publication of this paper.

\section{References}

[1] Doole, I. and Lowe, R. (2004) International Marketing Strategy: Analysis, Development and Implementation. 4th Edition, Cengage Learning, Boston.

[2] Doherty, N. and Ellis-Chadwick, F. (2010) Internet Retailing: The Past, the Present and the Future. International Journal of Retail and Distribution Management, 38, 943-965. https://doi.org/10.1108/09590551011086000

[3] Hagel, J. (1999) Net Gain: Expanding Markets through Virtual Communities. Journal of Interactive Marketing, 13, 55-65.

https://doi.org/10.1002/(SICI)1520-6653(199924)13:1<55::AID-DIR5>3.0.CO;2-C 
[4] Chaffey, D., Mayer R., Ellis-Chadwick, F. and Johnston, K. (2006) Internet Marketing: Strategy, Implementation and Practice. Pearson Education, London.

[5] Binod, K. and Neeraj, A. (2014) A Study of Performance Measurement of Online Retail Stores. Asian Academic Research Journal of Multidisciplinary, 1, 672-693.

[6] Phillips Consulting (2014) Online Shopping Survey Report. https://phillipsconsulting.net/insights/reports

[7] Liao, Z. and Cheung, M.T. (2002) Service Quality in Internet e-Banking: A User-Based Core Framework. IEEE International Conference on e-Technology, e-Commerce and e-Service, Hong Kong, China, 29 March - 1 April 2005, 628-631.

[8] Kolesar, M. and Galbraith, W. (2000) A Services-Marketing Perspective on e-Retailing: Implications for e-Retailers and Directions for Further Research. Internet Research, 10, 424-438. https://doi.org/10.1108/10662240010349444

[9] Delafrooz, N., Pain, H., Haron, S., Sidin, S. and Khatibi, A. (2009) Factors Affecting Attitude toward Online Shopping. African Journal of Business Management, 3, 200-209.

[10] Muhammad, U.S. and Nasir, U. (2011) Consumers' Attitude towards Online Shopping. M.Sc. Thesis, Gotland University, Gotland.

[11] Kim, C., Zhao, W. and Yang, K. (2008) An Empirical Study on the Integrated Framework of e-CRM in Online Shopping: Evaluating the Relationships among Perceived Value, Satisfaction, and Trust Based on Customers' Perspectives. Journal of Electronic Commerce in Organizations, 6, 1-19. https://doi.org/10.4018/jeco.2008070101

[12] Basu, A. and Muylle, S. (2003) Online Support for Commerce Processes by Web Retailers. Decision Support Systems, 34, 379-395. https://doi.org/10.1016/S0167-9236(02)00065-9

[13] Kotler, P. and Armstrong, G. (2012). Principles of Marketing. 14th Edition, Pearson Education, Inc., Upper Saddle River.

[14] Evanschitzky, H., Gopalkrishnan, R., Hesse, J. and Dieter, A. (2004) E-Satisfaction: A Re-Examination. Journal of Retailing, 80, 239-247. https://doi.org/10.1016/j.jretai.2004.08.002

[15] Wolfinbarger, M. and Gilly, M. (2003) Retail Quality: Dimensionalizing, Measuring and Predicting Retail Quality. Journal of Retailing, 79, 183-198. https://doi.org/10.1016/S0022-4359(03)00034-4

[16] Doherty, N.F. and Ellis-Chadwick, F.E. (2009) Exploring the Drivers, Scope and Perceived Success of e-Commerce Strategies in the UK Retail Sector. European Journal of Marketing, 43, 1246-1262. https://doi.org/10.1108/03090560910976474

[17] Levenburg, N. (2005) Delivering Customer Value Online: Analysis of Practices, Applications and Performance. Journal of Retailing and Consumer Services, 12, 319-331. https://doi.org/10.1016/j.jretconser.2004.11.001

[18] Srinivasan, S. Anderson, R. and Kishore, P. (2002) Customer Loyalty in e-Commerce: An Exploration of Its Antecedents and Consequences. Journal of Retailing, 78, 41-50. https://doi.org/10.1016/S0022-4359(01)00065-3

[19] Liang, T. and Lai, H. (2000) Electronic Store Design and Consumer Choice: An Empirical Study. Proceedings of the 33rd Hawaii International Conference on System Sciences, 7 January 2000, 10.

[20] Ayo, C., Ekong, O., Fatudimu, I. and Adebiyi, A. (2007) M-Commerce Implementation in Nigeria: Trends and Issues. Journal of Internet Banking and Commerce, 12, $1-15$. 
[21] Nwaeze, O. (2015) Top Twenty Online Shopping Stores in Nigeria. http://buzznigeria.com/top-20-online-shopping-stores-in-nigeria

[22] Gupta, P. (2015) Comparative Study of Online and Offline Shopping. M.Sc. Thesis, National Institute of Technology Rourkela, Odisha.

[23] Lynch, P., Kent, R. and Srinivasan, S. (2001) The Global Internet Shopper: Evidence from Shopping Tasks in Twelve Countries. Journal of Advertising Research, 41, 15-23. https://doi.org/10.2501/JAR-41-3-15-23

[24] Chiang, K. and Dholakia, R. (2003) Factors Driving Consumer Intention to Shop Online: An Empirical Investigation. Journal of Consumer Psychology, 13, 177-183. https://doi.org/10.1207/153276603768344898

[25] Giese, J. and Cote, J. (2000) Defining Customer Satisfaction. Academy of Marketing Science Review, 1, 1-24.

[26] Tse, D. and Wilton, P. (1988) Models of Consumer Satisfaction Formation: An Extension. Journal of Marketing Research, 25, 204-214. https://doi.org/10.1177/002224378802500209

[27] Kotler, P. and Keller, K. (2009) Marketing Management. Global Edition, Pearson Education Inc., Upper Saddle River.

[28] Levy, P. (2009) Measuring Customer Satisfaction. http://web.ebscohost.com/ehost/pdf?vid=5andhid=12andsid=3e223a11-3ffe-4951-b 082-735c8449be46\%40sessionmgr11

[29] Davis, F.D. (1989) Perceived Usefulness, Perceived Ease of Use, and User Acceptance of Information Technology. MIS Quarterly, 13, 319-340. https://doi.org/10.2307/249008

[30] Davis, F.D., Bagozzi, R.P. and Warshaw, P.R. (1992) Extrinsic and Intrinsic Motivation to Use Computers in the Workplace. Journal of Applied Social Psychology, 22, 1111-1132. https://doi.org/10.1111/j.1559-1816.1992.tb00945.x

[31] Jarvanpaa, S.L. and Todd, P.A. (1997) Consumer Reactions to Electronic Shopping on the World Wide Web. International Journal of Electronic Commerce, 1, 59-88. https://doi.org/10.1080/10864415.1996.11518283

[32] Vellido, A., Lisboa, P.J.G. and Meehan, K. (2000) Quantitative Characterization and Prediction of Online Purchasing Behavior: A Latent Variable Approach. International Journal of Electronic Commerce, 4, 83-104. https://doi.org/10.1080/10864415.2000.11518380

[33] Chung-Hoon, P. and Young-Gul, K. (2003) Identifying Key Factors Affecting Consumer Purchase Behavior in an Online Shopping Context. International Journal of Retail and Distribution Management, 31, 16-29. https://doi.org/10.1108/09590550310457818

[34] Flick, K. (2009) Assessing Consumer Acceptance of Online Shopping: Examining Factors Affecting Purchase Intentions. PhD Thesis, Northcentral University, Scottsdale.

[35] Cheung, C., Chan, G. and Limayem, M. (2005) A Critical Review of Online Consumer Behavior: Empirical Research. Journal of Electronic Commerce in Organizations, 3, 1-18. https://doi.org/10.4018/jeco.2005100101

[36] Chaffey, D. and Ellis-Chadwick, F. (2012) Digital Marketing: Strategy, Implementation and Practice. 5th Edition, Pearson Education Limited, London.

[37] Chaffey, D. and Smith, P. (2008) E-marketing Excellence: Planning and Optimizing Your Digital Marketing (E-Marketing Essentials). 3rd Edition, Routledge, Abingdon-on-Thames.

[38] Syed, S. and Norjaya, M. (2010) An Investigation into the Antecedents of Customer 
Satisfaction of Online Shopping. Journal of Marketing Development and Competitiveness, 5, 71-78.

[39] Shariful, I. (2015) An Analysis of Factors Affecting on Online Shopping Behavior of Consumers. European Journal of Business and Management, 7, 6-17.

[40] Esiri, E. (2015) E-Commerce in Nigeria: Market Trends and Consumer Behaviour. https://www.slideshare.net/GuillaumeRaffy/ecommerceng

[41] Basil, G., Anyadighibe, J., Edward, J. and Sunday, E. (2014) An Empirical Study of the Impact of Non-Store Retailing on Consumers' Satisfaction in Calabar Metropolis Nigeria. American International Journal of Contemporary Research, 4, 46-57.

[42] Akbar, S. and James, P.T. (2014) Consumers' Attitude Towards Online Shopping: Factors Influencing Employees of Crazy Domains to Shop Online. Journal of Management and Marketing Research, 14, 1.

[43] Ayo, C.K., Adewoye, J.O. and Oni, A.A. (2011) Business-to-Consumer e-Commerce in Nigeria: Prospects and Challenges. African Journal of Business Management, 5, 5109-5117.

[44] Olusoji, J., Ogunkoya, O., Lasisi, J. and Elumah, L. (2015) Risk and Trust in Online Shopping: Experience from Nigeria. International Journal of African and Asian Studies, 11, 71-77.

[45] Afolayan, D. (2014) The Evolution of a Mega City: The Case of Ibadan, Nigeria. https://www.sensorsandsystems.com/the-evolution-of-a-mega-city-the-case-of-ibad an-nigeria

[46] Rose, S., Spinks, N. and Isabel-Canhoto, A. (2015) Management Research: Applying the Principles. Routledge, Taylor and Francis, New York.

https://doi.org/10.4324/9781315819198 